\title{
Amyand's Hernia and Acute Appendicitis: Case Presentation in Basic Hospital of Chone
}

\author{
CrossMark \\ Orelvis Rodríguez Palmeroa, Liseidy Ordaz Marin ${ }^{b}$, María Del Rosario Herrera Velázquezc ${ }^{\text {, Agustín }}$ \\ Marcos García Andrade ${ }^{d}$
}

Manuscript submitted:09 June 2020, Manuscript revised: 18 July 2020, Accepted for publication: 27 August 2020

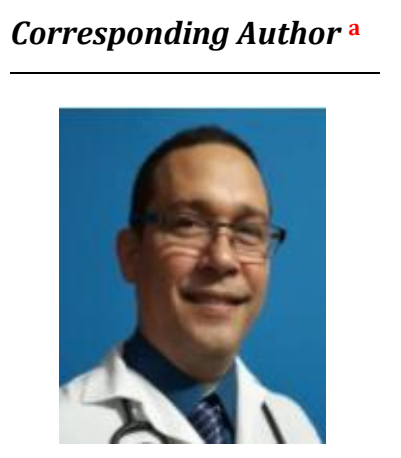

Keywords

apéndice cecal;

hernia de amyand;

hernia inguinal;

permanent protrusion;

petechiae;

\begin{abstract}
Present the case of a 66-year-old male patient, with a history of right inguinal hernia, who was referred to the emergency room at the IESS de Chone Basic Hospital in the north of the Manabí province, Ecuador, with symptoms of Abdominal pain of more than 24 hours of evolution located in the right iliac fossa and inguinal region on the same side, in the physical examination the hernia was impossible to reduce, so he was taken to the operating room, in the intervention the cecal appendix was found swollen within the hernial sac, a condition is known as Amyand's hernia.
\end{abstract}

\section{Contents}

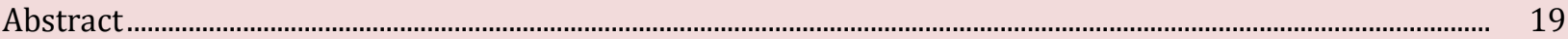

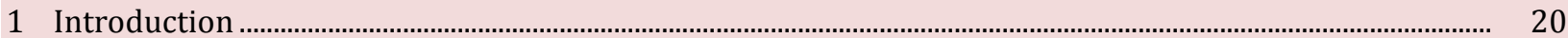

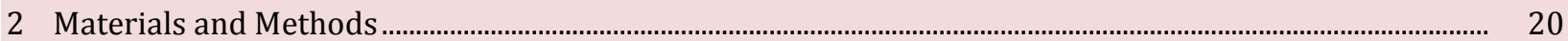

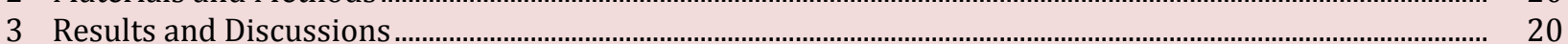

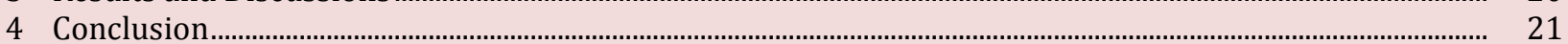

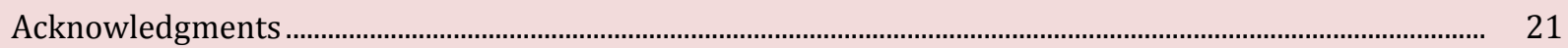

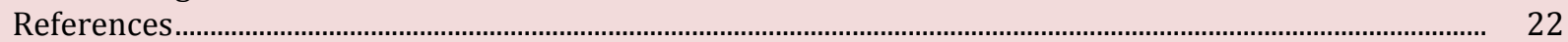

a Hospital Básico del IESS de Chone, Junín y Boyacá, Manabí, Ecuador

b Hospital Básico Jipijapa del ministerio de salud pública, Manabí, Ecuador

${ }^{\mathrm{c}}$ Universidad Estatal del Sur de Manabí, Campus Los Ángeles, Jipijapa, Manabí, Ecuador

d Hospital Básico del IESS de Chone, Junín y Boyacá, Manabí, Ecuador 


\section{Introduction}

The hernia is nothing more than the occasional or permanent protrusion or exit of a viscus or tissue or parts of these through a natural orifice or acquired from the abdominal wall (Etxabe et al., 2014; Morales-Cárdenas et al., 2015; Cankorkmaz et al., 2010). It is still common to find within the inguinal hernial sac the small intestine or omentum, more rarely the bladder, a Meckel's diverticulum (Littré's hernia) or a circumferential segment of the small intestine (Richter's hernia) (Gupta et al., 2005; Lopez \& Hernñandez, 2005; Contreras et al., 2008).

Dr. Claudius Amyand described appendicitis in 1736, in a child who had a chronic fistula of the right inguinal region, to which I performed an appendectomy, the cause of the acute inflammatory process was due to the perforation of the cecal appendix by a pin, from then on this type of hernia was baptized as Abraham's (Abraham, 2010).

\section{Material and Method}

Omentum is more rarely the bladder, a Meckel's diverticulum (Littré's hernia), or a circumferential segment of the small intestine (Richter's hernia) (Gupta et al., 2005; Lopez \& Hernñandez, 2005; Contreras et al., 2008). Dr. Claudius Amyand described appendicitis in 1736, in a child who had a chronic fistula of the right inguinal region, to which I performed an appendectomy, the cause of the acute inflammatory process was due to the perforation of the cecal appendix by a pin, from then on this type of hernia was baptized as Abraham's (Abraham, 2010; García-Cano et al., 2016; Muriel et al., 2016).

\section{Results and Discussions}

Case description $A$

A 66-year-old male patient with a history of right inguinal hernia of more than 5 years of evolution, who was referred to the emergency department of the IEES de Chone basic hospital, due to abdominal pain in the right iliac fossa and inguinal region right of more than 24 hours of evolution, with nausea, fever and taking the general state, in the physical examination an irreducible and painful right inguinal hernial sac was found, with marked peritoneal sensitivity and contracture of the right iliac fossa, the biometry with a leukocytosis out of 12,000 with 88 neutrophils, he was taken to the operating room with the diagnosis of strangulated inguinal hernia.

\section{Surgical findings}

In the operative act, a Nyhus type III inguinoscrotal hernia was found, with a dilated inguinal ring and sac that reached the scrotum, when opening it, an inflamed cecal appendix was found inside, with mesoedematous, peritoneum with petechiae and without local suppuration, spermatic cord and testicle without pathological alterations, an appendectomy, and repair of the hernial defect with polypropylene mesh was performed using the Liechtenstein technique. Favorable postoperative evolution with discharge at 72 hours without surgical complications. The consultation was followed for two months and the histopathological result reported acute appendicitis. In figure 1, a photo of the necrosis of the cecal appendix within the hernial sac is shown. 


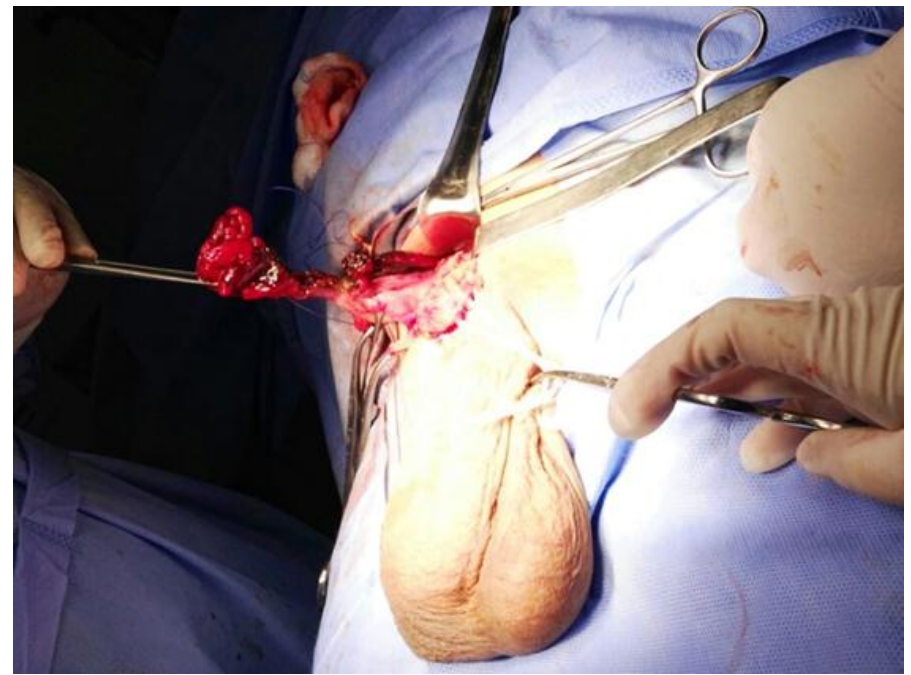

Figure 1. Photo of the necrosis of the cecal appendix within the hernial sac

\section{Discussion of the bibliography}

Claudius Amyand was the first surgeon to perform an appendectomy in an incarcerated inguinal hernia in an 11-year-old boy (Sancho et al., 2016). It was René Jacques Croissant de Garengeot, a French surgeon who first described a hernia of this type, four years earlier (Garcia et al., 2016; Sharma et al., 2007).

The prevalence of Amyand's hernia varies according to the series, between $0.19 \%$ and $1.7 \%$ of all operated inguinal hernias, which is why it is considered a rare pathology (Ivashchuk et al., 2014). The prevalence of appendicitis within a hernial sac is even lower, it is between $0.07 \%$ and $0.13 \%$ of total appendicitis (Agirre et al., 2014; Inan et al., 2009).

For Ortega León, the prevalence of Amyand's hernia is around 1\% of operated hernias and the picture associated with appendicitis is even less frequent from 0.10 to $0.15 \%$ (Monteagudo et al., 2015). In Ecuador, there are several reported cases, such as the one published by Ramírez Rivera et al. In a 45-day-old infant with bilateral inguinal hernia, where the appendix was found in the right hernial sac (Sharma et al., 2007).

\section{Conclusion}

It is concluded that the prevalence of Amyand's hernia remains low at around 1\%, even though more and more cases are reported in the world literature when it is associated with appendicitis, the priority of the case is focused on performing the appendectomy to eliminate the septic focus and secondly the repair of the hernial wall defect. The repair with the use of a prosthetic mesh of the hernial defect remains controversial due to the possibility of local infection due to acute appendicitis, despite this, this therapeutic option is currently increasing.

\section{Acknowledgments}

I am grateful to two anonymous reviewers for their valuable comments on the earlier version of this paper.

Palmero, O. R., Marin, L. O., Velázquez, M. D. R. H., \& Andrade, A. M. G. (2020). Amyand's hernia and acute appendicitis: Case presentation in Basic Hospital of Chone. International Journal of Health Sciences, 


\section{References}

Abraham, F. (2010). Abraham Arap JF. Hernias de la ingle en CiCirugía de las hernias de la pared abdominal. ECIMED, La Habana, 2010; Cap II; tema 7: 105-108. Estudio de caso (ECIMED).

Agirre, E., Prieto, M., García, A., García, J., Sarriugarte, A., \& C. A. (2014). Hernia de Amyand (tipo 2 de Losanoff) diagnosticada preoperatoriamente y tratada mediante hernioplastia con malla biológica, 2(4),162-172. http://dx.doi.org/10.1016/j.rehah.2014.04.003

Cankorkmaz, L., Ozer, H., Guney, C., Atalar, M. H., Arslan, M. S., \& Koyluoglu, G. (2010). Amyand's hernia in the $\begin{array}{llll}\text { children: } & \text { a single } & \text { center } & \text { experience. Surgery, 147(1), }\end{array}$ https://www.sciencedirect.com/science/article/pii/S0039606009006084

Contreras, R., Garcia, J., Gonzalez, J., Rojas Octavia, A. R., \& Murillo, A. (2008). Hernia de Amyand del lado izquierdo: revisión de la bibliografía y comunicación de un caso. Revista de Especialidades MédicoQuirúrgicas, 13(2).

Etxabe, LA, Calvo, MP, Etxebarría, AG, González, JMG, Lasarte, AS, \& Alonso, AC (2014). Amyand hernia (Losanoff type 2) diagnosed preoperatively and treated by hernioplasty with biological mesh. Revista Hispanoamericana de Hernia , 2 (4), 169-172. https://doi.org/10.1016/j.rehah.2014.04.003 elsevier

Garcia, E., MaArtinez, J., Rosales, C. H., Alvaro, J., \& Franco, F. (García Cano E, Martínez Gasperin J, Rosales Pelaez C, Hernández Zamora V, Montiel Jarquín JA, Franco Cravioto F. (2016). Hernia de Amyand y apendicitis complicada; presentación de un caso y elección de tratamiento quirúrgico. Cirugía y Cirujanos. 84(1), 54-57. https://doi.org/10.1016/j.circir.2015.06.012

García-Cano, E., Martínez-Gasperin, J., Rosales-Pelaez, C., Hernández-Zamora, V., Montiel-Jarquín, J. Á., \& Franco-Cravioto, F. (2016). Amyand's hernia and complicated appendicitis; case presentation and surgical treatment choice. Cirugía y Cirujanos (English Edition), 84(1), 54-57. https://doi.org/10.1016/j.circen.2015.12.004

Gupta, S., Sharma, R., \& Kaushik, R. (2005). Left-sided Amyand's hernia. Singapore Medical Journal, 46(8), 425425.

Inan, I., Myers, P., Hagen, M., Gonzalez, M., \& Morel, P. (2009). Hernia de Amyand: 10 años de experiencia. 7(4), 198-202. https://doi.org/10.1016/S1479-666X(09)80084-X

Ivashchuk, G., Cesmebasi, A., Sorenson, E., Blaak, C., Tubbs, S., \& Loukas, M. (2014). Hernia de Amyand: una revisión. Medical Science, 20, 140-146. https://doi.org/10.12659/MSM.889873

Lopez, P., \& Hernñandez, L. (2005). Hernia de Amyand: presentación de dos casos. Revista de Especialidades Médico-Quirúrgicas, 4(1).

Monteagudo, R., Toctaguano, C., Ramírez, L., \& Farril, H. (2015). Hernia de Amyand: a propósito de un caso. Revista Cubana de Cirugía, 54(2), 172-176.

Morales-Cárdenas, A., Ploneda-Valencia, C. F., Sainz-Escárrega, V. H., Hernández-Campos, A. C., Navarro-Muniz, E., López-Lizarraga, C. R., \& Bautista-López, C. A. (2015). Amyand hernia: Case report and review of the literature. Annals of medicine and surgery, 4(2), 113-115. https://doi.org/10.1016/j.amsu.2015.03.007

Muriel, J. S., Gallud, A. T., Pastor, P. G., Rubio, M. L., Argüelles, B. G., \& Lledó, J. A. B. (2016). Hernia de Amyand: presentación de tres casos y revisión bibliográfica. Revista Hispanoamericana de Hernia, 4(3), 107-111. https://doi.org/10.1016/j.rehah.2015.05.001

Sancho, M., \& al, e. (2016). Revista Hispanoamericana de Hernia, 4(3), 107-111.

Sharma, H., Gupta, A., Sharma, N., Memon, B., \& Memon, M. (2007). Hernia de Amyand: un informe de 18 pacientes consecutivos durante un período de 15 años. 11(3), 235-238. 


\section{Biography of Authors}

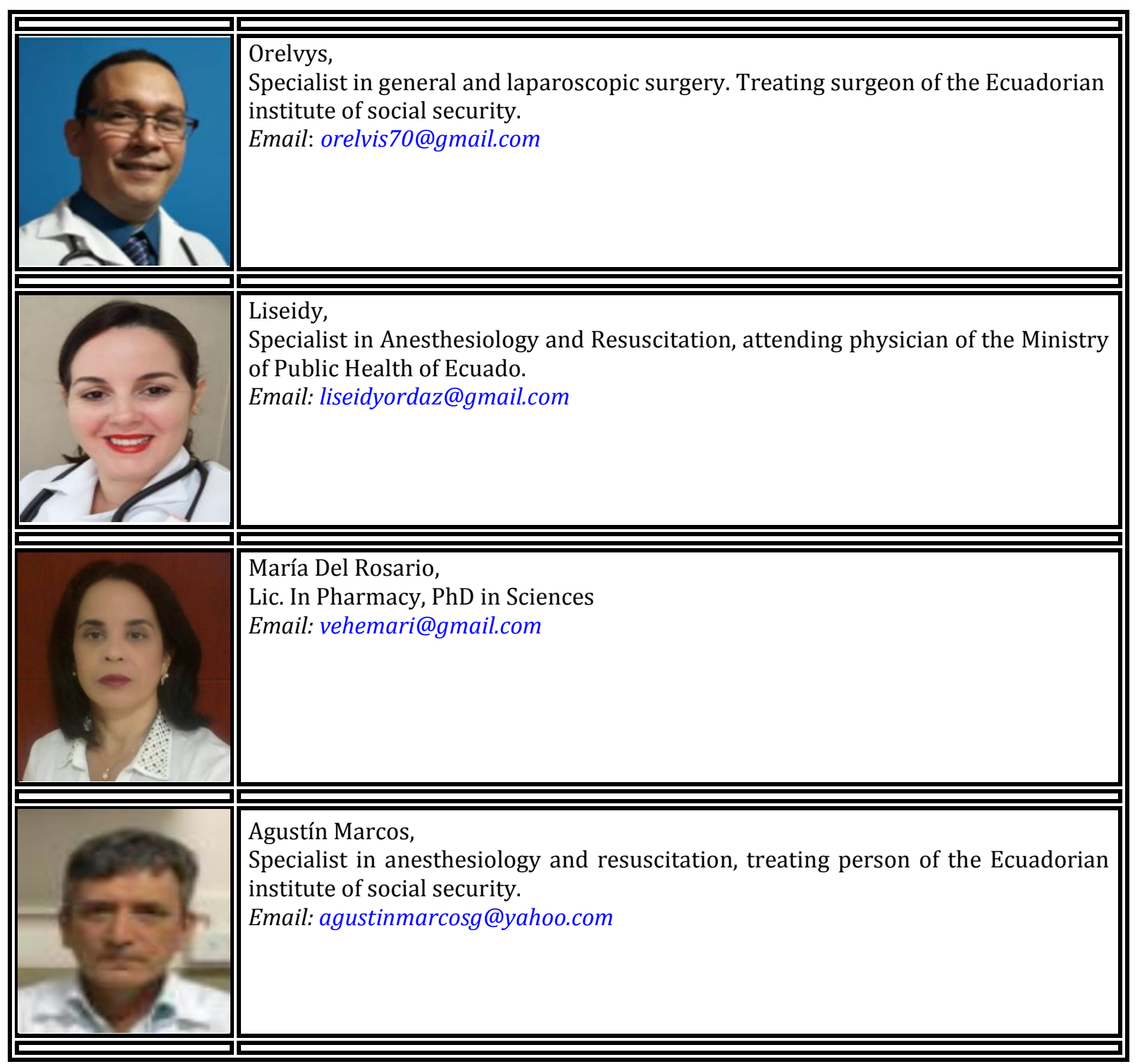

Palmero, O. R., Marin, L. O., Velázquez, M. D. R. H., \& Andrade, A. M. G. (2020). Amyand's hernia and acute appendicitis: Case presentation in Basic Hospital of Chone. International Journal of Health Sciences, 4(2), 19-23. https://doi.org/10.29332/ijhs.v4n2.440 